\title{
TIPOLOGI RUMAH TRADISIONAL KAMPUNG WANA DI LAMPUNG TIMUR
}

\section{TYPOLOGY OF TRADITIONAL HOUSE OF WANA VILLAGE IN EAST LAMPUNG}

\author{
Ani Rostiyati \\ Balai Pelestarian Nilai Budaya Bandung \\ Jl. Cinambo No. 136 Ujungberung - Bandung \\ e-mail: anirostiyati@yahoo.com
}

\begin{abstract}
Abstrak
Tipologi rumah tradisional Kampung Wana merupakan gambaran mengenai bentuk, denah, tata ruang yang tercermin melalui kebudayaan masyarakat Kampung Wana terhadap lingkungan alam dan sosialnya. Dalam konteks itu, tipologi rumah tradisional di Kampung Wana terkandung aspek kosmologis berupa adaptasi terhadap lingkungan alam dan nilai-nilai yang memiliki makna sebagai pengatur kehidupan masyarakat untuk menciptakan tertib sosial. Namun, dalam perkembangan teknologi dan kemajuan zaman bukan tidak mungkin arsitektur rumah tradisional khususnya mengenai tipologi dan bentuk rumah tersebut mengalami perubahan, jika demikian bagaimana prospek tipologi rumah tradisional pada masyarakat di Kampung Wana ke depan manakala mereka tetap bertahan, ataupun sebaliknya, bagaimana mereka merespon perubahan itu. Penelitian ini menggunakan pendekatan kualitatif dan merupakan penelitian etnografi. Bila dilihat dari kedalaman analisisnya, maka jenis penelitian bersifat deskriptif, yakni menganalisis dan menyajikan fakta secara sistematik sehingga dapat lebih mudah untuk dipahami dan disimpulkan. Penelitian deskriptif menggambarkan secara sistematik dan akurat fakta mengenai populasi atau bidang tertentu, dalam hal ini tentang tipologi arsitektur rumah tradisional pada masyarakat Kampung Wana. Adapun pengambilan data melalui observasi, wawancara mendalam pada sejumlah informan, dan studi pustaka. Untuk pengambilan gambar, dilakukan foto dan membuat sketsa atau denah rumah.
\end{abstract}

Kata kunci: tipologi, rumah tradisional, Kampung Wana.

\section{Abstract}

The typology of traditional house of Kampung Wana is the image of shape, plans, and lay-out depicted through the culture of Kampung Wana society towards their natural and social environment. They contain cosmological aspects such as adaptation to the natural environment and the values that control the lives of the people in creating social order. However, the development of technology and the progress of the times have given way to changes in the architecture of Kampung Wana's traditional houses. Would they be preserved or how do they endure in such changes? The author conducted qualitative approach and this is an ethnographic research. From the depth of the analysis this is a descriptive research that is analyzing and presenting data systematically in order to make it easy to be understood and to be concluded. Descriptive research describes facts concerning certain population or field systematically and 
accurately. Data were obtained through observation, in-depth interviews with a number of informants and bibliographic study as well. The author also took picture and made sketches of the house plans.

Keywords: typology, traditional houses, Kampung Wana.

\section{A. PENDAHULUAN}

Manusia memiliki kebutuhankebutuhan dasar yang dapat memberinya rasa nyaman, aman dan tenang (Ember \& Ember, 1973:3-15). Salah satunya adalah kebutuhan papan, khususnya tradisi membangun rumah. Adapun tradisi membangun atau mendirikan sebuah bangunan rumah, disadari atau tidak, merupakan sebuah tradisi berarsitektur ${ }^{1}$ yang telah dilakukan oleh suku-suku bangsa di Indonesia sejak zaman dahulu. Setiap manusia memerlukan sebuah tempat untuk berlindung dari panas dan hujan, mereka mulai mendirikan sebuah bangunan yang akhirnya menjadi tempat tinggal. Setiap suku bangsa memiliki bentuk arsitekturnya sendiri. Bentuk arsitektur di sini dapat juga dikatakan bangunan serta bagaimana mendirikan bangunannya. Arsitektur pada suatu suku bangsa selalu berhubungan dengan kepercayaan dan nilai-nilai yang dianut, adat-istiadat, iklim dan kondisi alam setempat, serta mata pencaharian.

Adapun batasan tetang arsitektur tradisional telah banyak diberikan oleh para ahli yang menaruh perhatian pada pemenuhan kebutuhan manusia akan tempat tinggal dan lingkungan sosial di

\footnotetext{
${ }^{1}$ Berarsitektur, sebagaimana dimaksudkan oleh Nicolas (2003), salah satu dari hasil karya arsitektur adalah arsitektur rumah tradisional. Arsitektur ini ditumbuhkembangkan oleh suatu masyarakat tertentu tanpa arsitek yang merupakan cerminan kehidupan sosial masyarakat suatu daerah. Lebih jauh lagi arsitektur rumah tradisional ada yang hadir berdasarkan suatu komunitas yang mempunyai pola kehidupan sosial yang kuat dalam memegang teguh adat. Jadi karya arsitektur dibuat berdasarkan tradisi dalam hukum adat, yaitu adanya aturan-aturan tertentu dalam estetika bentuk rupa, ruang dan tata cara membangun rumah secara tradisi.
}

sekitar pemukimannya. Secara keseluruhan dari berbagai macam pendapat yang terkait dengan arsitektur tersebut, dapat disimpulkan, bahwa arsitektur tradisional merupakan suatu bangunan yang bentuk, tipologi, struktur, fungsi ragam hias, dan cara membuatnya diwariskan dari satu generasi ke generasi berikutnya, serta dapat dimanfaatkan sebagai tempat untuk melaksanakan segala aktivitas kehidupan.

Arsitektur rumah tradisional ditumbuhkembangkan oleh suatu masyarakat pendukung suatu kebudayaan sebagai cerminan dari kehidupan sosial masyarakat dan kebudayaannya. Karena itu, arsitektur rumah tradisional sebagai perwujudan dari suatu masyarakat yang mempunyai pola kehidupan sosial yang kuat dalam memegang teguh adat-istiadat.

Foster (1969-155) mengatakan bahwa arsitektur rumah tradisional tumbuh dalam suatu masyarakat sebagai cerminan dari kehidupan kebersamaan yang berkaitan dengan tempat dan waktu, sehingga dapat memberikan gambaran tentang suatu bentuk, tipologi serta ruang yang tercipta berdasarkan adaptasi alamiah pada lingkungan natural, untuk menciptakan keselarasan sosial budaya terhadap lingkungan alam yang ada di sekelilingnya.

Sehubungan dengan itu maka di sini akan mengkaji rumah tradisional yang ada di Lampung Timur yakni Kampung Wana Kecamatan Melinting. Seperti diketahui, setiap suku bangsa selalu memiliki bangunan arsitektur tradisional sebagai cermin dari kebudayaan yang ditumbuhkannya sendiri, sehingga keberadaannya dapat memberikan ciri serta identitas dari suatu suku bangsa sebagai pendukung suatu kebudayaan tersebut. Berkaitan dengan itu, arsitektur tradisional yang beranekaragam tersebut perlu dikaji lebih dalam mengenai tipologi, struktur, 
fungsi, dan maknanya. Untuk membatasi masalah, kajian ini lebih memfokuskan mengenai tipologi rumah tradisional. Dalam konteks itu, masalah yang diajukan adalah bagaimana tipologi (bentuk, tata ruang) rumah tradisional di Kampung Wana dan apakah dengan adanya perubahan kebudayaan yang sejalan dengan perkembangan kemajuan zaman berpengaruh terhadap tipologi rumah tradisional pada masyarakat Kampung Wana. Jika demikian bagaimana prospek rumah tradisional pada masyarakat di Kampung Wana ke depan manakala mereka tetap bertahan, ataupun sebaliknya, bagaimana mereka merespon perubahan itu.

Penelitian ini mengambil lokasi di Kampung Wana dengan alasan kampung ini memiliki ciri khas tersendiri, karena hampir sebagian besar bentuk rumahnya adalah rumah panggung yang berarsitektur tradisional dan sarat dengan makna serta nilai. Ditinjau dari fungsinya, rumah panggung digunakan untuk beradaptasi dengan lingkungannya yakni menghindari adanya banjir, hewan liar, tempat menyimpan kayu bakar atau hasil bumi, dan gempa. Di Kampung Wana, eksistensi bentuk rumah panggung masih diterapkan, karena lingkungan kebun dan hutan masih tetap menjadi lingkungan dominan di kampung ini. Hirarki ruang rumah panggung yang diterapkan dalam rumah Kampung Wana ini cukup simpel dan linear dari bagian depan hingga belakang rumah. Dari hirarki tersebut sudah dapat dibayangkan bahwa rumah dengan bentuk linear adalah memanjang ke belakang. Tapi dalam penerapannya ada 2 jenis kelinearan yang dipakai, yaitu linear lurus dan linear L. Bentuk linear tersebut dikarenakan tata ruang rumah harus sesuai dengan aturan adat yakni dari ruang beranda depan ke arah belakang yakni ruang tamu, ruang keluarga, dapur, dan beranda samping. Keunikan inilah yang menjadi alasan mengapa Kampung Wana menjadi lokasi penelitian. Adapun rumah di Kampung Wana didirikan di atas tanah milik pribadi atau tanah warisan, karena pada awal mendirikan rumah mereka menebang hutan yang kemudian diakui menjadi miliknya. Keunikan lain adalah arsitektur tradisional rumah masyarakat Kampung Wana tidak saja dilihat sebagai bentuk, tetapi juga sebagai ruang yang terjadi karena kebutuhan, adat kebiasaan, pandangan hidup, norma, dan tatanan nilai. Keunikan juga terlihat dari produk hutan sebagai bahan kayu pembuatan rumah dan atap dengan kemiringan kurang lebih $45 \%$ yang merupakan salah satu karakteristik arsitektur tropis Asia.

\section{B. METODE PENELITIAN}

Metode penelitian ini menggunakan pendekatan kualitatif dan merupakan penelitian etnografi. Etnografi adalah sebuah penelitian tentang masyarakat (suku bangsa), dalam hal ini tentang masyarakat Kampung Wana, khususnya tentang tipologi arsitektur rumah tradisionalnya. Pendekatan kualitatif yang digunakan untuk menganalisis terhadap dinamika hubungan antarfenomena yang diamati dengan menggunakan logika ilmiah. Pendekatan kualitatif ini tidak menekankan data-data yang bersifat angka (numerikal), melainkan data yang bersifat gagasan, ide, nilai-nilai, dan pikiran yang tidak bisa diukur dengan angka. Bila dilihat dari kedalaman analisisnya maka jenis penelitian bersifat deskriptif, yakni menganalisis dan menyajikan fakta secara sistematik sehingga dapat lebih mudah untuk dipahami dan disimpulkan. Penelitian deskriptif menggambarkan secara sistematik dan akurat fakta mengenai populasi atau bidang tertentu, dalam hal ini tentang tipologi arsitektur rumah tradisional pada masyarakat Kampung Wana. Adapun pengambilan data melalui observasi, wawancara mendalam pada sejumlah informan, dan studi pustaka. Untuk pengambilan gambar, dilakukan dengan memotret dan membuat sketsa atau denah. 


\section{HASIL DAN BAHASAN 1. Kampung Wana}

Kampung Wana secara geografis berada di daerah pesisir timur Lampung Timur, tepatnya di Kecamatan Melinting. Kampung Wana memiliki batas wilayah, sebelah utara berbatasan dengan Desa Sri Bawono, sebelah barat dengan Desa Waringin Jaya, sebelah timur dengan Desa Tanjung Haji, sebelah selatan dengan Desa Tanjung Haji, dan sebelah selatan dengan Desa Sumbarhardi. Menuju Kampung Warna cukup mudah dijangkau karena telah dibangun infrastruktur berupa jalan raya melalui jalur Bandar Lampung-Jabing Labuhan Meringgai dan melalui lintas timur dengan rute jalan BakauheniLabuhan Maringgi-Jabing. Jarak Kampung Wana ke Kecamatan Melinting kurang lebih 2 Km, ke Kabupaten Lampung Timur kurang lebih $64 \mathrm{Km}$, dan ke ibu kota Bandar Lampung kurang lebih $85 \mathrm{Km}$. Secara umum lahan di Kampung Wana terbagi dalam beberapa bagian antara lain perladangan/kebun, pemukiman, sawah, dan rawa.

Di Kampung Wana selain penduduk etnis asli Melinting juga bermukim masyarakat etnis lain seperti Jawa, Banten dan lainya. Tentu saja hal ini terkait dengan potensi ekonomi dan mata pencaharian yang menjanjikan di daerah ini. Kelompok yang datang kemudian juga tidak terlepas adanya program kolonisasi Hindia-Belanda yang berlanjut ke era transmigrasi di abad 20 oleh pemerintah Republik Indonesia.

Mata pencaharian utama penduduk Kampung Wana adalah bercocok tanam. Wilayahnya yang subur menjadikan berbagai jenis tanaman tumbuh dengan subur. Mata pencaharian utama penduduk pada umumnya adalah di bidang pertanian, terutama perkebunan lada dan pertanian ladang (jagung, ketela, pisang, pepaya, kelapa) serta bertanam padi rawa hujan.

Wilayah Kampung Wana terdiri dari 14 dusun atau 14 RW dan 53 RT. Sebagian besar penduduknya adalah bekerja sebagai petani. Pada mulanya mereka tidak mengenal pertanian sawah, mereka hanya bertani di ladang dan kebun, namun karena pengaruh masuknya transmigran dari Jawa lama kelamaan mengenal pertanian sawah. Oleh karena sistem pengairan kurang bagus, maka pertanian sawah di Kampung Wana menggunakan tadah hujan.

Penduduk di Kampung Wana pada tahun 2012 tercatat 9348 jiwa, terdiri dari 4799 laki-laki dan 4549 perempuan. Menurut usia, penduduk Kampung Wana terdiri dari 0-15 tahun berjumlah 2555 jiwa, 16-55 tahun berjumlah 5552 orang, dan di atas 55 tahun berjumlah 1241 orang. Jumlah usia produktif lebih banyak dibandingkan dengan usia anak-anak dan lansia. Di bidang agama, masyarakat Kampung Wana sebagian besar memeluk agama Islam yakni 9291 orang, Katolik berjumlah 38 orang, dan Hindu 19 orang. Komposisi penduduk berdasarkan kelompok-kelompok etnik yang bermukim di Kampung Wana meliputi kelompok etnik orang Melinting yang merupakan kelompok etnik Lampung asli, kelompok etnik Sunda, terutama yang berasal dari daerah Banten, serta kelompok etnik Jawa.

\section{Rumah Kampung Wana}

Sistem kekerabatan masyarakat Kampung Wana yang merupakan orang Melinting pada dasarya adalah tipe keluarga luas. Pada awalnya lahan maupun bahan untuk perumahan cukup tersedia, masing-masing anak yang telah menikah umumnya langsung membuat rumah tinggal baru di sekitar rumah tinggal orang tua laki-laki. Hal ini yang melatarbelakangi pertumbuhan jumlah rumah tinggal di satu permukiman tradisional etnik Lampung pada umumnya.

Lahan rumah (petegian), adalah satu areal yang dipergunakan untuk bangunan rumah, termasuk bagian halaman yang belum ada bangunannya. Areal lahan ini diolah, diratakan dan ditinggikan untuk kemudian didirikan rumah serta ditempatkan umpak-umpak batu (pematu). Umpak-umpak batu tersebut menjadi 
tempat bertumpunya tiang-tiang kayu bangunan. Samping kiri dan kanan halaman rumah, pada umumnya dibiarkan terbuka tanpa pagar pembatas, sehingga bisa berinteraksi secara bebas dengan tetangga. Hal itu juga mencerminkan adanya pola hubungan sosial yang erat serta terbuka antarkeluarga di Kampung Wana, yang pada dasamya memiliki akar kekerabatan keluarga luas.

Sekalipun telah ada gejala perubahan, khususnva pada penggunaan unsur bahan rumah tinggal, namun di Kampung Wana masih mempertahankan bentuk arsitektur rumah tradisional Lampung, sebagai sub budaya arsitektur tradisionaI Sumatera umumnya, yakni rumah panggung yang menggunakan bahan kayu.

Secara umum rumah orang Kampung Wana dapat dibagi ke dalam 2 tipe yakni rumah tinggal (hunian) dan rumah sementara. Rumah tinggal adalah rumah yang dihuni oleh seluruh keluarga, sedangkan rumah sementara adalah yang berada di luar rumah tinggal yakni di ladang (kebun). Sedangkan rumah tinggal dapat dibedakan berdasarkan kualitas bahan yang digunakan, pengolahan bahan, unsur-unsur ornamen serta ukuran luasnya, yaitu tipe rumah mewah, tipe rumah biasa yang merupakan tipe kebanyakan, dan tipe rumah sederhana. Rumah mewah dengan ukuran besar dimiliki oleh suku dagang yakni seorang pedagang yang kaya raya, sedangkan rumah kebanyakan dimiliki oleh masyarakat biasa. Pada aspek ukuran luas, besarnya serta kualitas bahan, tipe rumah mewah dan tipe rumah biasa sesungguhnya tidak banyak berbeda. Unsur pembeda dari keduanya yang paling menonjol adalah pada aspek pengolahan bahan kayu serta unsur ornamennya, baik unsur ornamen pada bagian luar (eksterior) maupun bagian dalam (interior) bangunan. Tipe rumah mewah menggunakan unsurunsur omamen berupa ukiran kayu, baik ukiran tembus dengan motif-motif sulur daun, flora, serta kaligrafi yang dibuat pada bagian-bagian venilasi di atas pintu dan atau jendela, serta pahatan hias tiangtiang rumah, daun-daun pintu dan jendela, terutama yang nampak dari luar. Sedangkan untuk rumah kebanyakan lebih sederhana ornamennya dan jenis kayu yang digunakan bukan merbau. Jadi secara umum rumah tinggal yang mewah maupun kebanyakan hampir sama struktur tipologisnya.

Jika dipilah-pilah bentuk bangunan rumah panggung di daerah penelitian, sebagaimana juga rumah panggung di lain tempat, terdiri dari bagian bawah (kaki), bagian tengah (badan), serta atas (atap). Bagian bawah (kaki) bangunan yang dimaksud berupa tiang-tiang kayu yang disusun secara berderet melebar dan memanjang mengikuti denah rumah yang berbentuk persegi panjang, yang dalam istilah setempat disebut mahanyuk'an. Bagian melebar (bangkok) adalah bagian yang tampak dari depan dan belakang rumah, sedangkan memanjang (hanyukuni) adalah bagian yang tampak dari samping rumah. Tiang-tiang kayu yang secara teknis berfungsi sebagai penyangga atap serta pengikat bagian badan tersebut bertumpu pada umpak-umpak batu yang berfungsi sebagai fondasi bangunan rumah. Bahan batuan dan batu umpak tersebut umumnya adalah jenis batuan andesit.

Bentuk rumah panggung menyisakan ruang bawah rumah, yaitu ruang antara permukaan tanah dan bagian bawah lantai rumah yang lazim dikenal sebagai kolong rumah (bah lamban). Secara tradisi bagian bawah rumah ini biasa dimanfaatkan sebagai kandang ternak (sapi, kambing, ayam), tempat menumbuk padi, serta tempat penyimpanan peralatan pertanian atau rumah tangga dan kandang ternak. Pada awalnya di masa lampau bagian ruang bawah tidak dimanfaatkan secara khusus, hanya untuk menghindari ancaman binatang serta luapan air banjir. Namun dalam perkembangannya, bagian bawah rumah tersebut dimanfaatkan sebagai tempat pengolahan serta 
penyimpanan hasil bumi seperti lada, merica, singkong, dan padi.

Pembagian fungsi atau tata ruang bagian badan rumah pada rumah panggung Kampung Wana mencerminkan nilai-nilai serta aturan-aturan atau norma-norma pergaulan sosial keluarga. Berikut ini ruangan di rumah tradisional Kampung Wana, terdiri dari:

1. Tepas (teras depan)

2. Ruang tamu (pengidangan ragah) $\rightarrow$ laki-laki

3. Ruang keluarga (pengidangan sebay) $\rightarrow$ perempuan

4. Kamar (pates)

5. Kamar samping (juyou pates)

6. Ruang penghubung (jembatan)

7. Dapur (gakhang); dan

8. Beranda belakang (tadah embun)

Tepas (beranda atau teras terbuka), yaitu ruang lapang pertama setelah menaiki tangga masuk rumah. Namun sebelumnya terdapat halaman atau pekarangan depan rumah (tengahbah/terambah) yaitu pekarangan bagian depan rumah yang biasa dimanfaatkan sebagai tempat menjemur hasil bumi. Sebenarnya di ujung tangga naik juga terdapat satu ruang kecil yang disebut gakhang hadap, yaitu tempat air untuk membersihkan kaki sebelum masuk ke beranda. Tipe rumah mewah biasanya memiliki dua buah tangga masuk yang ditempatkan ditepi kiri dan kanan depan rumah. Sedangkan rumah biasa posisi tangga umumnya ditempatkan di tepi kanan depan rumah. Sisi depan dan samping ruang beranda (tepas) ini terbuka atau nampak dari luar yang diberi pembatas pagar teralis kayu (kandang rarang). Ruang beranda (tepas) berfungsi untuk menerima tamu atau tempat anggota keluarga bersantai melepas lelah, terutama pada siang hari. Lantai ruang beranda serta bagian ruang yang lain untuk tipe rumah mewah dan rumah biasa umumnya menggunakan lantai papan kayu. Sedangkan tipe rumah sederhana menggunakan batang bambu yang disusun serta diikat dengan rotan.

Ruang kedua setelah beranda adalah ruang pertama di dalam rumah yang dalam istilah setempat disebut ruang pengidangan/luwah ragah/lapang luar. Ruang yang berdenah persegi empat sama sisi itu berfungsi sebagai ruang musyawarah, ruang untuk kaum laki-laki mengobrol, juga biasa dipakai sebagai ruang tempat tidur laki-laki, termasuk ayah dan atau tamu laki-laki (dengan memasang tabir dan menggelar tikar dan kasur). Ayah atau keluarga laki-laki tidak selamanya tidur di kamar istrinya, kecuali pada saat melakukan hubungan sebagai suami istri.

Ruang ketiga setelah melewati ruang pengidangan luwah/ragah melalui pintu yang ada di tepi kanan atau tengah dinding pemisah antarruang, adalah ruang lapang lom, yang memiliki ukuran sama luasnya dengan ruang lapang luar. Ruang ini terbagi dalam empat fungsi ;

1. Sebagai ruang tempat musyawarah: obrolan kaum wanita (pengidangan sebay) yang juga biasa dipakai sebagai tempat tidur anak-anak wanita yang telah lepas menyusui atau tamu wanita. Sub ruang ini menempati belahan kiri ruang dan arah depan yang bersambungan tanpa pembatas.

2. Ruang makan untuk menjamu tamu dekat.

3. Ruang tidur (pates) yang diberi dindingdinding penyekat. Ruang tidur ini digunakan sebagai tempat tidur istri dan anak-anak yang masih menyusui.

4. Ruang yang sama luasnya disebut lembe pates yang berfungsi sebagai ruang yang digunakan sewaktu-waktu untuk anggota keluarga sakit, uzur dan atau tempat memandikan jenazah anggota keluarga meninggal. Lembe pates bisa pula dimanfaatkan sebagai tempat menaruh barang-barang rumah tangga.

Ruang keempat dari badan rumah, yakni ruang antara dapur dan lembe pates yang disebut dengan jembatan atau geragal. Pada rumah yang memiliki 
ukuran lebih luas, antara ruang dapur dihubungkan oleh semacam bangunan koridor penghubung yang disebut geragal/jembatan/jerambah. Bagian geragal ini diberi atap yang sama tingginya dengan atap ruang dapur. Ruang dapur menempati bagian ruang yang cukup luas. Selain sebagai tempat tungku perapian (pawon/sakelak) untuk memasak sehari-hari serta tempat menyimpan persediaan bahan makanan, dapur juga berfungsi sebagai tempat penyimpanan berbagai peralatan memasak maupun peralatan bertani.

Seperti halnya di bagian depan rumah, di bagian luar samping atau belakang dapur terdapat pula sebuah gakhang (gakhang dapur), yaitu ruang kecil tempat pencuci kaki sebelum memasuki rumah, yang menghubungkan dapur dengan pekarangan samping atau belakang rumah. Saat ini, setelah penduduk tidak banyak lagi yang memanfaatkan kuwayan yaitu tempat mandi dan mencuci di mata air dekat rawa, gakhang dapur banyak yang difungsikan menjadi kamar mandi; tempat mencuci dengan memanfaatkan air dan sumur gali atau sumur pompa yang dibuat di sekitarya. Air kotor mengucur ke bawah melalui sela-sela bambu yang menjadi lantai gakhang.

Bagian atap bangunan pada mulanya lazim menggunakan bahan daun rumbia, namun dewasa ini penggunaan bahan rumbia mulai banyak ditinggalkan dengan memilih genting sebagai penggantinya. Atap rumah tradisional di Kampung Wana berbentuk persegi panjang yang dikenal dengan istilah bubung perahu yang tampak seperti perahu terbalik atau limas memanjang.

Adapun bangunan-bangunan lain yang terkait sebagai kebutuhan langsung dengan tradisi subsistensi serta agama dan budaya masyarakat di Kampung Wana antara lain adalah bangunan di ladang dan kebun, masjid, tempat pengajian, sesat (tempat musyawarah adat) serta pemakaman. Bangunan di ladang atau kebun disebut kebau dan sapau. Kedua jenis bangunan itu pada dasarnya hampir sama yaitu berbentuk bangunan panggung yang sangat sederhana dengan menggunakan bahan-bahan yang ada di sekitar kebun atau ladang. Denah bangunan lazimnya berbentuk segi empat atau persegi panjang dengan ukuran sekitar $2 \times 2$ meter. Kedua jenis bangunan biasa memakai atap alang-alang atau daun rumbia. Bagian badan bangunan diberi dinding penyekat dari bambu atau kayu. Dalam tradisi berladang di wilayah Lampung, jika kesuburan lahan telah jenuh, bangunan ini biasanya ditinggalkan begitu saja hingga lapuk dan petani kemudian membuat bangunan baru di ladang atau kebun.

Adapun bangunan masjid sebagai tempat ibadah di Kampung Wana di masa lalu berbentuk bangunan panggung yang terbuat dari bahan kayu. Namun saat ini masjid berupa bangunan tembok, hanya pada bagian atapnya masih memiliki bentuk atap masjid tradisional, yaitu atap limas tumpang dua. Fungsi masjid selain sebagai tempat sembahyang, pada perkembangannya telah berganti fungsi menjadi bangunan sesat. Bangunan sesat adalah bangunan adat etnik Lampung sejak masa pra-Islam yang berfungsi sebagai tempat musyawarah adat. Di masa berkembang agama Islam, berbagai permusyawarahan adat dilaksanakan di masjid.

Bangunan lain adalah tempat pengajian sebagai salah satu unsur bangunan sarana sosial keagamaan. Tempat ini berfungsi sebagai tempat anakanak dan remaja belajar membaca AlQuran. Selain bangunan masjid dan tempat mengaji, terdapat klaster-klaster pemakaman. Klaster pemakaman yang dimaksud adalah areal pemakaman keluarga dan umum. Klaster pemakaman itu menempati areal lahan di dekat lahan rawa tadah hujan, yaitu pada areal lahan yang disebut sebagai areal hutan penyangga air, di mana areal itu tidak 
dimanfaatkan secara langsung sebagai lahan pertanian penduduk.

Untuk lebih detailnya, berikut ini akan diuraikan tipologi rumah tradisional Kampung Wana. Tipologi yang dimaksud meliputi bentuk keseluruhan bangunan berdasarkan denah, tata ruang, dan bentuk bangunan berdasarkan atap, serta ornamenornamen yang terdapat pada rumah tersebut. Tipologi ini terbagi dua, yaitu bangunan rumah tinggal dan rumah sementara.

\section{Tipologi Rumah}

Bagian ini menggambarkan tipologi rumah hunian dan rumah sementara yang terdapat di Kampung Wana. Rumah hunian adalah rumah yang dihuni oleh keluarga batih maupun luas. Rumah hunian berada di lingkungan permukiman masyarakat Kampung Wana. Adapun rumah tinggal sementara adalah rumah yang hanya dihuni pada waktu-waktu tertentu dan berada di luar permukiman. Rumah tinggal sementara berada di ladang atau sawah yang berdasarkan istilahnya terbagi dua, yaitu kebou dan sapeu.

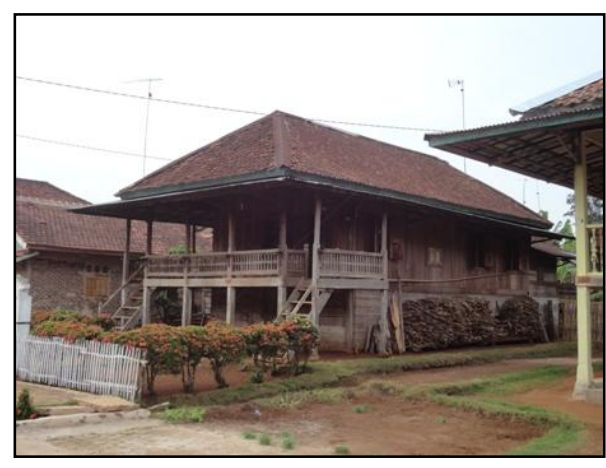

Gambar 1. Rumah di Kampung Wana

\section{a. Tipologi Rumah Hunian}

Pada umumnya rumah hunian pada masyarakat Kampung Wana adalah rumah panggung berbentuk persegi panjang. Panjang dan lebar bangunan disesuaikan dengan luas dan bentuk lahan yang dimiliki oleh seseorang. Karenanya pada rumah hunian di Kampung Wana, dapat ditemui variasi luas rumah, ada yang memiliki rumah yang sangat luas dan ada juga yang memiliki rumah hunian yang lebih kecil. Luas rumah tersebut ditentukan oleh status seseorang, yaitu kepemilikan harta benda dan lahan yang digunakan untuk hunian. Perbedaan luas tidak berkaitan dengan status sosial seseorang, artinya baik rakyat biasa maupun tokoh adat (penyimbang) dapat memiliki rumah dengan luas yang proporsional dengan lahan. Ada rakyat biasa yang memiliki rumah yang lebih luas daripada penyimbang; dan ada juga rumah penyimbang yang lebih luas daripada rumah yang dimiliki oleh rakyat biasa.

Pola permukiman Kampung Wana memiliki ciri mengikuti poros jalan. Bentuknya persegi panjang dan wajah rumah yang menghadap ke jalan adalah bagian lebar atau bagian pendek dari rumah. Sedangkan bagian panjang dari rumah tersebut memanjang dari depan ke belakang. Rumah hunian berarsitektur tradisional dapat ditemui dengan ciri yang sangat mencolok yaitu rumah panggung berbahan kayu dan umumnya berwarna gelap karena bahan kayu yang dipakai adalah kayu merbau atau kayu kenango. Rumah-rumah tersebut memiliki tiangtiang yang kokoh dan dindingnya tersusun dari papan kayu. Rumah panggung tersebut berderet di sepanjang jalan utama Kampung Wana.

\section{1) Atap Rumah}

Atap rumah merupakan bagian dari struktur rumah yang berfungsi untuk melindungi bangunan dan penghuninya dari deraan terik matahari, hujan, serta memberikan rasa aman bagi para penghuni rumah tersebut. Atap rumah menempati posisi paling atas dari struktur rumah yang dibentuk sedemikian rupa untuk menutupi bangunan dan sekaligus mengalirkan air hujan langsung ke tanah.

Bentuk atap yang umum ditemui pada rumah tradisional Kampung Wana adalah berbentuk limas seperti perahu terbalik. Atap ini terdiri dari 4 (empat) bagian atap yang dihubungkan oleh bubungan yang memanjang dari depan 
bangunan hingga bagian belakang bangunan. Pada bagian bawah atap dilengkapi dengan talang air agar aliran air hujan tidak terlalu deras menghujam tanah. Bagian atap rumah tradisional Kampung Wana berada sekitar kurang lebih 6 meter dari permukaan tanah dan disangga olehtiang-tiang (akheui) yang berdiri dari tanah hingga ujung bawah bagian dalam dari atap. Akheui tersebut berada baik di luar maupun di dalam rumah untuk menyangga seluruh bagian ruangan rumah, termasuk juga untuk menyangga atap.

Selain bentuk atap limas, terdapat pula atap yang memiliki bentuk pelana. Atap seperti ini terdiri dari 2 bagian atap yang dihubungkan oleh bubungan yang memanjang dari depan ke belakang. Perbedaannya dengan atap limas adalah pada bagian muka dan belakang dari atap ditutupi oleh papan kayu hingga bagian bawah bubungan. Sementara pada atap limas, bagian muka dan bagian belakang atapnya ditutup dengan genting.

Pada masa dahulu, penutup atap rumah tradisional Kampung Wana dari rumbia. Rumbia merupakan jenis pepohonan palem yang hidup di rawa sekitar Kampung Wana. Untuk membuat atap dari rumbia, penduduk setempat memilih daun rumbia tua dari pohon yang masih muda. Daun rumbia merupakan bahan atap yang cukup baik dan sifatnya tahan lama, namun demikian tiap tahun perlu dilakukan penggantian rumbia.

Penggunaan rumbia kini ditinggalkan seiring dengan berkurangnya pohon rumbia di Kampung Wana. Berkurangnya pohon tersebut dikarenakan laju tekanan penduduk yang mendorong terjadinya alih fungsi lahan, dari lahan produktif menjadi lahan hunian. Pada masa sekarang, seiring berkembangnya teknologi, atap dari daun rumbia sudah tidak ditemukan lagi dan beralih pada penggunaan genting. Umumnya genting yang digunakan berjenis genting palentong yang didatangkan dari Pulau Jawa. Genting tersebut mereka datangkan dari Banten atau Cirebon.

\section{2) Tiang Rumah}

Tiang atau akheui merupakan
komponen penting dalam rumah tradisional Kampung Wana. Akheui yang digunakan dari kayu merbau, berbentuk balok dengan tampak muka bujur sangkar, berukuran sekitar $15 \mathrm{Cm}$ x $15 \mathrm{Cm}$. Pada beberapa rumah terdapat akheui-akheui yang telah diprofil/dipahat untuk menambah estetika.

Akheui didirikan di atas tanah dengan menggunakan sebuah umpak dari batu. Akheui merupakan penyangga rumah panggung dan merupakan bagian utama dari rangka rumah tradisional untuk menopang lantai, dinding, dan atap. Karena fungsinya sebagai penopang, akheui harus terbuat dari bahan kayu yang keras dan kuat seperti kayu merbau atau setidaknya kayu kenango. Dengan jenis kayu demikian, selain kekuatan dalam menopang rumah, kayu jenis tersebut mengeluarkan semacam minyak yang dapat mencegah serangan serangga pemakan kayu seperti rayap ataupun agas (aneui), yaitu sejenis serangga pemakan kayu yang meninggalkan jejak berupa butiran-butiran isi kayu yang halus.

Umumnya pada sebuah rumah terdapat 5-6 akheui di bagian depan dan belakang rumah, sementara dari depan ke belakang terdapat 24 akheui yang juga merupakan tanda pembatas ruangan dalam rumah. Akheui adalah kerangka rumah panggung yang saling berikatan satu dengan yang lain melalui papan-papan penyambung. Dalam proses penyambungannya, akheui-akheui tersebut tidak menggunakan paku, melainkan menggunakan pasak dari kayu yang sangat kuat atau bambu betung yang telah tua. Pemasangan pasak-pasak tersebut dilakukan dengan melubangi akheuiakheui terlebih dahulu untuk kemudian ditanamkan pasak-pasak pada bagian yang telah dilubangi tersebut.

Selain akheui, penopang lantai adalah akheui tunggul. Akheui tunggul ini tidak sampai ke atas dan tingginya hanya mencapai bagian palang penahan papan 
lantai rumah. Akheui tunggul tidak dapat terlihat dari dalam rumah, namun akheui ini dapat dilihat fungsinya sebagai penyangga apabila kita masuk ke bagian bawah (kolong).

Seperti halnya akheui, pemasangan akheui tunggul sebagai penopang papan lantai umumnya tidak menggunakan paku namun menggunakan pasak kayu atau pen. Dengan cara yang sama pada pasak akheui, papan-papan lantai, poros-poros akheui tunggul, dan kudo-kudo dilubangi terlebih dahulu. Setelah dilubangi pasak-pasak kayu yang telah disiapkan kemudian ditanam pada sambungan antara akheui tunggul dengan kudo-kudo dan antara papan lantai dengan kudo-kudo.

\section{3) Dinding}

Dinding rumah tradisional Kampung Wana terbuat dari papan kayu merbau atau kenango. Perbedaan dari kedua jenis kayu tersebut adalah pada warna. Kayu merbau memiliki warna yang kehitam-hitaman sementara kayu kenango memiliki warna yang cenderung putih. Kedua kayu tesebut memiliki daya tahan yang tinggi terhadap cuaca panas dan hujan juga tahan terhadap serangan serangga pemakan kayu.

Dinding pada rumah tradisional Kampung Wana yang berusia tua pada umumnya tidak dilapisi cat melainkan dibiarkan warna asli dari kayu yang digunakan. Untuk dinding rumah yang berbahan kayu kenango akan nampak berwarna keputih-putihan, sementara yang berbahan kayu merbau akan tampak berwarna coklat kehitam-hitaman. Walaupun tidak dilapisi cat, akan tetapi rumah tetap kuat, karena bahan kayu tersebut memiliki cairan minyak pelindung sehingga daya tahan terhadap cuaca relatif kuat.

Dinding papan pada rumah tradisional Kampung Wana biasanya terdiri dari 1 lapis papan saja, kecuali pada rumah milik suku dagang yang memiliki 2 lapis papan. Pada rumah yang memiliki 1 lapis papan, akheui dapat terlihat dari dalam atau dari luar rumah. Berbeda dengan rumah yang memiliki 2 lapis dinding papan, akheui-akheuinya tidak terlihat karena tertutupi oleh dinding papan. Sebaliknya jika pemasangan dinding papan berada di dalam rumah, akheui akan terlihat dari luar rumah. Batas ruangan lebih mudah diidentifikasi berdasarkan susunan akheui yang terlihat, baik dari dalam rumah maupun dari luar rumah karena terdapat bagian dari akheui yang tidak tertutupi oleh dinding papan.

Umumnya tinggi ruangan rumah untuk rumah tradisional Kampung Wana bergantung pada panjang selembar papan yang dijadikan dinding. Tidak ada keseragaman mengenai panjang lembaran dinding papan tersebut untuk seluruh rumah, ada rumah dengan papan dinding yang memiliki panjang sekitar 2,5 M, rumah lainnya memiliki papan dinding 3 M. Kebutuhan terhadap papan dinding dapat dihitung berdasarkan luas rumah, rata-rata memerlukan 200 papan untuk menjadi satu rumah.

Untuk menahan dinding, terdapat palang-palang horizontal yang tersambung pada akheui. Palang-palang tersebut dipasak pada akheui sebelum ditempelkan dinding papan. Setelah selesai dipasangi pasak dan terhubung pada akheui kemudian papan-papan dinding mulai dideretkan dan dipasangi pasak pada palang di bagian kiri dan kanan dari papan dinding tersebut untuk mengunci agar papan tidak bergerak ataupun bergeser.

Pada ujung bawah dinding papan terdapat lantai dan di ujung atasnya adalah plafon. Dinding papan tidak dipasak baik pada lantai maupun plafon, tetapi dibiarkan bebas untuk mengurangi daya tekan. Hal ini dimaksudkan jika lantai mengalami tekanan akibat bobot yang berat, dinding tidak terpengaruh oleh tekanan atas lantai tersebut dan dinding tetap berada pada posisinya. Termasuk jika lantai mengalami runtuh, dinding tidak akan terpengaruh karena tidak terkunci pada lantai. 


\section{4) Lantai}

Lantai merupakan bagian dari rumah yang dijadikan pijakan dan tempat aktivitas penghuni rumah. Lantai-lantai pada rumah tradisional Kampung Wana terbuat dari deretan papan kayu merbau atau kayu kenango. Papan-papan lantai tersebut berderet mengikuti bentuk ruangan dalam rumah tradisional Kampung Wana.

Dalam pemasangannya, antara satu rumah dengan rumah yang lain terdapat adanya keseragaman. Pemasangan lantai rumah mengikuti pola vertikal terhadap bentuk ruangan atau bentuk rumah. Papanpapan lantai dipasang memanjang dari muka rumah hingga ke bagian dalam rumah. Hal tersebut dilakukan karena pada bagian bawah rumah terdapat akheuiakheui tunggul yang berderet horizontal terhadap bidang rumah.

Ukuran setiap papan lantai pada rumah tradisional Kampung Wana relatif memiliki kesamaan. Umumnya setiap lembar papan lantai kayu memiliki panjang mencapai $4 \mathrm{M}$ dan lebar mencapai $0,25 \mathrm{M}$. Di bawah lantai papan, terdapat palangpalang yang ditunjang oleh akheui tunggul. Palang-palang tersebut berjarak antara 30 $\mathrm{Cm}-40 \mathrm{Cm}$ setiap barisnya. Untuk memperkuat dan mengunci lantai papan agar tidak bergerak dan stabil, pada lantai papan tersebut dipasang pasak kayu yang menembus papan hingga palang kayu yang berada di bawahnya. Dengan terkuncinya lantai kayu tersebut, maka lantai tidak bergeser akibat pergerakan manusia di atasnya dan lantai kayu tersebut dapat menahan beban berat di atasnya baik yang bersifat statis maupun dinamis.

Di bagian dapur, terdapat tungku (awu) yang bertumpu pada lantai papan rumah panggung. Berbeda dengan tungku pada umumnya, tungku tersebut berdiri, ditunjang oleh susunan kerangka kayu balok dan papan sebagai alas tungku. Di bawah rumah, akheui tunggul, palangpalang, dan lantai papan menjadi kekuatan penyangga tungku tersebut. Beban tungku menjadi bertambah karena pada bagian bawah tungku diberi batang pisang (gebog) sebagai penahan panas, di atasnya diamparkan papan-papan sebagai alas tungku dan diberi lapisan tanah/pasir untuk mencegah bunga api yang dapat menimbulkan kebakaran pada kayu.

\section{5) Pintu}

Pintu pada rumah tradisional Kampung Wana terbuat dari kayu merbau. Pintu depannya terdiri dari 4 (empat) daun pintu yang terdiri dari 2 daun pintu yang terbuka keluar dan 2 daun pintu yang terbuka ke dalam, sedangkan pintu di dalam rumah bervariasi, ada yang memiliki 2 daun pintu dan adapula yang memiliki 1 daun pintu. Kekhasan yang dapat dilihat pada bagian pintu adalah di bagian pintu masuk rumah atau pintu depan. Pintu dibagian ini terdiri dari 2 daun pintu yang terbuka keluar yang bingkainya terbuat dari rangka kayu dan badannya terbuat dari papan. Dua daun pintu tersebut memiliki ornamen yang berfungsi mengalirkan udara masuk. Dua daun pintu di belakangnya berbingkai kayu namun badannya berupa kaca. Daun pintu tersebut memiliki fungsi sebagai jalan masuk cahaya, terutama cahaya pada siang hari.

Tinggi pintu dapat mencapai lebih dari 2,5 meter dan pada daunnya terdapat ornamen untuk memperindah daun pintu. Selain itu, di atas daun pintu juga dapat ditemui ornamen yang selaras dengan ornamen daun pintu. Umumnya ornamenornamen pada pintu adalah daun melur yang dikombinasikan dengan kaligrafi, bunga melati, ataupun binatang seperti ular atau naga.

\section{6) Jendela}

Jendela pada rumah tradisional Kampung Wana merupakan bagian penting sebagai sirkulasi udara dan tempat masuknya cahaya matahari pada siang hari. Setiap unit jendela terdiri dari kusen dan daun jendela yang ukurannya relatif besar, hingga mencapai 1,2 $\mathrm{M}$ tingginya dengan lebar setiap lembar daun jendela mencapai $0,5 \mathrm{M}$. 
Seperti halnya pintu, jendela pada bagian depan rumah terdiri atas 4 daun jendela. Jendela ini terdiri dari 2 daun jendela yang terbuka keluar dan bingkainya terbuat dari rangka kayu serta badannya terbuat dari papan. Dua daun jendela pada bagian luar tersebut memiliki ornamen yang berfungsi sebagai ventilasi udara. Daun jendela di bagian dalam terdiri dari bingkai kayu dan dilapisi kaca. Fungsi jendela kaca adalah sebagai jalan masuk cahaya pada siang hari.

Kusen jendela pada rumah tradisional Kampung Wana bersatu dengan palang horizontal yang mengunci dinding papan. Dengan begitu, maka palang dapat memiliki fungsi ganda, selain sebagai pengunci dinding juga merupakan kusen sebagai dudukan jendela yang melintang horizontal. Akheui sebagai tiang horizontal dapat digunakan sebagai batang kusen yang berdiri vertikal.

\section{b. Tipologi Rumah Sementara}

Rumah sementara di Kampung Wana terbagi atas 2 (dua) jenis yaitu sapeu dan kebau. Kedua rumah sementara ini memiliki bentuk yang sangat sederhana jika dibandingkan dengan rumah hunian. Hal tersebut berkaitan dengan sifat rumah yang hanya dihuni sementara waktu saja. Baik sapeu maupun kabeu biasanya terletak di ladang tadah hujan milik warga Kampung Wana. Ladang tersebut berada tidak jauh dari lokasi permukiman warga Kampung Wana, baik di bagian utara maupun selatan dari permukiman. Rumah sementara tersebut biasanya dipakai istirahat setelah bekerja di ladang atau juga sebagai tempat penyimpanan sementara hasil bumi yang baru dipanen (kebau). Sedangkan sapeu biasanya hanya untuk beristirahat, karena itu lebih kecil bangunannya. Petani dapat menginap di rumah sementara tersebut saat menjelang panen untuk menghindarkan padi dari serangan binatang pemakan padi seperti tikus. Pada bangunan tersebut biasanya juga dilengkapi tungku untuk memasak air atau nasi dan terdapat alat dari kayu utuk memisahkan padi dari batang padi.

\section{1) Sapeu}

Sapeu merupakan bangunan sementara yang didirikan dari bambu dengan bentuk yang sederhana dan terbuka. Tiang bambunya berjumlah empat dan tiang pada bagian depan lebih tinggi daripada bagian belakang. Atapnya berbahan rumbia yang mudah didapat di sekitar ladang. Pada bagian dalam hanya terdapat tempat amparan bambu untuk duduk atau menyimpan hasil bumi. Beberapa sapeu memiliki amparan tikar yang menutupi deretan bambu tempat duduk, beberapa sapeu lainnya tidak dilengkapi dengan tikar, hanya deretan bambu saja.

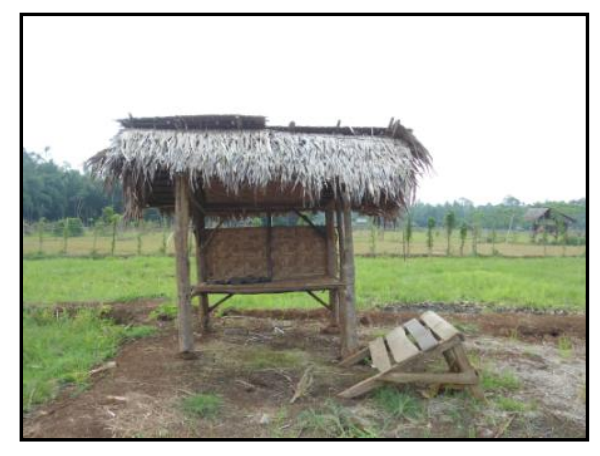

Gambar 2. Sapeu

Sumber: Dok. APBNP 2013

\section{b. Kebou}

Berbeda dengan sapeu, kebou merupakan bangunan yang lebih kompleks wujudnya. Kebou biasanya merupakan rumah panggung kecil yang memiliki ruangan untuk tidur dan dapur di dalamnya. Selain untuk menyimpan hasil bumi, kebou dapat ditinggali untuk sementara waktu, terutama saat menunggu panen atau saat menanam padi.

Pada bangunan kebou, biasanya bagian teras, rumah dan dapur bersatu dengan ruangan untuk tidur. Kebou memiliki kerangka yang terdiri dari 8 buah akheui untuk menopang badan rumah dengan tinggi mencapai 2,5 meter. Bangunan tersebut memiliki atap genting 
dan dinding terbuat dari papan kayu dan memiliki pintu lengkap dengan kuncinya, juga memiliki jendela yang dapat dibuka tutup.

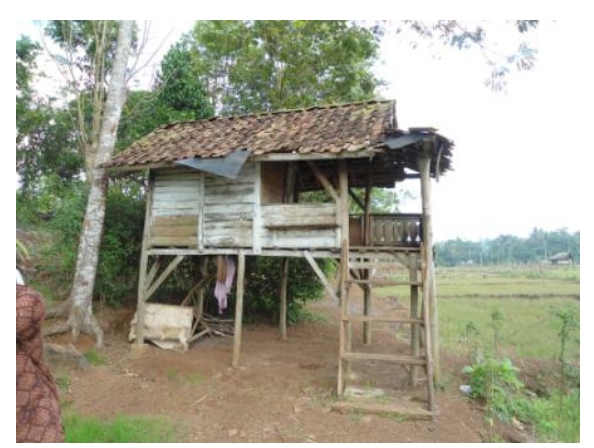

Gambar 3. Kebou

Sumber: Dok. APBNP 2013

\section{PENUTUP}

Tampak bahwa arsitektur rumah tradisional merupakan bentuk hasil budaya yang memberi corak tersendiri dan menunjukkan nilai yang khas. Tipologi rumah tradisional di Kampung Wana berkaitan dengan 3 sistem yakni sistem lingkungan, bangunan, dan manusia yang diresapi dalam bentuk penataan permukiman tersebut. Adanya aturanaturan dalam pembuatan rumah tradisional di Kampung Wana seperti adanya ruang bawah rumah, pemakaian pen, pemilihan kayu harus yang terbaik, bentuk atap perahu, dan lain sebagainya, bila dikaji memberi keselarasan dalam lingkungan dan keteraturan pada bangunan itu sendiri.

Dengan adanya perkembangan teknologi dan modernisasi, tentu ada pergeseran atau perubahan. Perubahan tersebut terutama karena pengaruh teknologi, ekonomi, agama dan pendidikan. Pengaruh teknologi misalnya kalau dahulu pemasangan bahan-bahan bangunan tidak memakai paku melainkan diikat atau pen, namun sekarang sudah banyak yang menggunakan paku. Atap bangunan biasanya memakai rumbia, namun dengan adanya teknologi dari luar kemudian memakai genting. Batu bata dan semen menggantikan kayu dan papan.
Pengaruh ekonomi seperti bahanbahan dari kayu/papan karena sudah mulai langka dan mahal, sudah banyak yang diganti dengan bata/semen karena lebih ekonomis. Ukuran besarnya rumah disesuaikan dengan kebutuhan dan kemampuan. Rumah sekarang tidak sebesar rumah pada zaman dahulu lagi. Cara mengerjakan bangunan umumnya dilakukan dengan gotong royong, tetapi sekarang sudah mulai melemah dan dikerjakan oleh tenaga/tukang profesional dengan sistem upah atau borongan. Kalau dahulu dilakukan upacara secara lengkap mulai dari sebelum mendirikan rumah dan sesudah mendirikan rumah. Sekarang adanya pengaruh agama, upacara yang dilakukan mulai berkurang hanya sematamata bersifat do'a selamatan terutama pada waktu akan menempati rumah. Dalam aspek pendidkan (ilmu pengetahuan) juga memberi pengaruh dalam perubahan arsitektur, khususnya dalam hal pertukangan. Kalau dahulu ada tukang yang benar-benar ahli dalam membuat ornamen hiasan dan kayu, sekarang tukang tersebut sangat sulit didapat bahkan tidak ada lagi. Tukang sekarang tidak lagi memiliki kemampuan pengetahuan yang sama dengan tukang dahulu, mereka lebih menggunakan cara-cara modern.

Dari uraian di atas, dapat dikatakan bagaimana prospek tipologi rumah tradisional Kampung Wana ke depan. Masyarakat Kampung Wana pada dasarnya masih mempertahankan rumah panggung berarsitektur tradisional. Ini tampak dari keberadaan rumah panggung di Kampung Wana yang berjumlah lebih dari 60 persen dari jumlah rumah keseluruhan. Meskipun demikian, tidak dipungkiri bangunan tradisional di Kampung Wana dalam bentuk, tipologi dan fungsinya sudah mulai berubah, banyak rumah yang sudah rusak atau roboh dimakan usia tidak dibangun lagi menjadi rumah panggung. Dengan alasan tidak memiliki dana dan harga kayu mahal, maka mereka membangun atau merenovasi rumahnya dengan dinding 
tembok dan bukan rumah panggung (rumah biasa).

Secara umum, arsitektur rumah tradisional khususnya tipologi Kampung Wana masih tetap eksis meskipun arus modernisasi dan teknologi mulai menerpa. Meskipun ada beberapa kondisi rumah tradisional di Kampung Wana banyak yang sudah dimakan usia dan itu perlu perbaikan. Jika tidak ada perhatian dari pemerintah dan adanya usaha-usaha penyelamatan maka lambat laun akan menuju kepunahan. Itu sebabnya upaya pelestarian salah satu warisan budaya bangsa ini perlu dilakukan.

Dengan melihat tipologi (bentuk) rumah tradisional Kampung Wana, beberapa saran yang dapat diberikan adalah sebagai berikut:

1. Masyarakat dapat mengadopsi tipologi rumah tradisional Kampung Wana yang tanggap lingkungan dan tanggap bencana, khususnya gempa bumi.

2. Kampung Wana yang ditetapkan sebagai destinasi pariwisata dan juga merupakan world heritage dan mini architecture village, khususnya wisata budaya sejak tahun 1991, pemerintah daerah perlu secara serius melestarikan dan mengupayakan pemeliharaan rumah tradisional Kampung Wana dengan tepat. Salah satu cara adalah memberi bantuan, merenovasi, atau mengupayakan harga kayu agar terjangkau. Jika tidak maka secara cepat rumah-rumah tradisional Kampung Wana akan musnah dan kehilangan statusnya sebagai world heritage.

3. Diharapkan ada upaya pemerintah untuk mensosialisasikan keberadaan arsitektur tradisional Lampung dengan berbagai aspeknya, agar menjadi lokal genius yang dibanggakan dan diperhitungkan oleh masyarakat lain.

4. Para perancang bangunan di daerah Lampung, terlebih perkantoran pemerintah maupun swasta bisa memasukkan unsur-unsur arsitektur tradisional Lampung ke dalam desainnya disesuaikan dengan kebutuhan bangunan.

\section{DAFTAR SUMBER}

\section{Buku}

Dagur, Antony Bagul. 1997.

Kebudayaan Manggarai Sebagai Salah Satu Khasanah Kebudayaan Nasional, Surabaya:Ubhara Press.

Djafar. Hasan, dan W. Anwar Falah. 1995.

Prasasti Batu Dari Sumber Hadi Daerah Lampung Tengah (Suatu

Informasi). Dalam Jurnal Penelitian Balar No. 1

Ember \& Melvin Ember. 1973.

Cultural Anthropology. New York: Appleton-Century- Crofts.

Fatah, W. Anwar dan Tony Djubiantono. 1994. Laporan Penemuan Situs Baru Di Desa Wana Kecamatan Perwakilan Meliting, Kabupaten Lampung Tengah. Balar Bandung.

George M Foster, 1969. Applied Anthropology Boston: Little B rown.

Hadikusuma SH, Uhlman et all. 1985.

Adat Istiadat Daerah Lampung. Proyek Inventarisasi dan Dokumentasi Kebudayaan Daerah. Depdikbud Kanwil Propinsi Lampung.

Harun, Ismet Berlgawan. 2011. Arsitektur Rumah dan Permukiman Tradisional di Jawa Barat. Bandung: Dinas Parbud Prov. Jabar.

Kent, Susan. 1990.

Domestic Architecture and The Use of Space. Cambridge University Press. Cambridge.

Koentjaraningrat. 1980.

Pengantar Ilmu Antropologi. Jakarta: Aksara Baru.

1981.

Beberapa Pokok Antropologi Sosial, Jakarta: Dian Rakyat.

1987.

Kebudayaan, Mentalitas dan Pembangunan. Jakarta: Gramedia. 
Prasetya, Edhi. 2002.

Arsitektur Tradisional Cibal, Manggarai, Flores Barat; Kajian Sistem

Budaya dan Lingkungan Permukiman, Thesis Magister Teknik Arsitektur Universitas Diponegoro.

Prijotomo, Joseph, 1997.

Materi Kuliah Arsitektur Nusantara, Pasca Sarjana FTSP, ITS Surabaya.

Rapoport, Amos. 1969.

House Form and Culture. Prentice Hall Inc. New York.

1982.

The Meaning of The Built Environment. Sage Pubications Ltd. London.

Wiryoprawiro, Zein. 1993.

Ciri-Ciri Arsitektur Tradisional Indonesia, Materi Kuliah SPA, FTSP ITS, Surabaya.

Rusydi, Umar Drs. Et all. 1986/1987.

Arsitektur Tradisional Daerah Lampung., Proyek Inventarisasi dan Dokumentasi Kebudayaan Daerah. Depdikbud Kanwil Propinsi Lampung.

Sayuti, Hasan. 1985.

Hubungan Lampung Dengan Kesultanan Banten dan Palembang, DalamPerspektif Sejarah, seminar Sejarah Nasional IV, Depdikbud.

Saifudin Azwar. 1997.

MetodePenelitian. Yogyakarta:Pustaka Pelajar.

\section{Internet}

"Melihat Kampung Wisata Wana, Kecamatan Melinting", diakses dari http:// www. radarlampung.co.id, tanggal 27 Desember 2012.

Asal Mula Keratuan Ratu Melinting dan Keratuan Darah Putih, diakses dari http://bdlok.blogspot.com, tanggal 27 Desember 2012. 
